\title{
Campylobacter helveticus sp. nov., a new thermophilic species from domestic animals: characterization, and cloning of a species-specific DNA probe
}

\author{
John Stanley, ${ }^{1 *}$ A. P. Burnens, ${ }^{2}$ D. Linton, ${ }^{1}$ S. L. W. On, ${ }^{1}$ M. Costas ${ }^{1}$ and R. J. Owen ${ }^{1}$ \\ ${ }^{1}$ National Collection of Type Cultures, Central Public Health Laboratory, 61 Colindale Avenue, London NW9 5HT, UK \\ ${ }^{2}$ Swiss National Reference Laboratory for Foodborne Diseases, Institute for Veterinary Bacteriology, University of Berne, \\ Langass-Strasse 122, CH-3012 Berne, Switzerland
}

(Received 21 April 1992; revised 24 July 1992; accepted 31 July 1992)

\begin{abstract}
An atypical group of thermophilic catalase-negative Campylobacter strains, the 'CH' (Swiss) group, can be recovered from faeces of domestic cats and dogs after selection by filtration, or with the antibiotic cefoperazone. This group of strains shows no relative DNA homology with any species in rRNA superfamily VI (Vandamme $e t$ al., 1991, International Journal of Systematic Bacteriology 41, 88-103) except with four thermophilic Campylobacter species, notably $C$. upsaliensis. The group is homogeneous and possesses a DNA base composition, cellular morphology at the electron microscope level and phenotypic properties characteristic of Campylobacter. Nonetheless it is distinct from known species of Campylobacter in terms of conventional bacteriological tests, total cellular protein profile, rRNA gene profile, and genomic DNA homology. On the basis of an integrated study of phenotype and genotype, we conclude that these bacteria constitute a previously undescribed species for which we propose the name Campylobacter helveticus sp. nov. A species-specific recombinant DNA probe was cloned from the designated type strain (NCTC 12470) for use in identification and further analysis of the epidemiology, pathogenicity and transmission of $C$. helveticus.
\end{abstract}

\section{Introduction}

The genus Campylobacter as now defined (Vandamme et al., 1991) is the outcome of considerable taxonomic refinement, the details of which have been extensively reviewed (Penner, 1988; Vandamme \& De Ley, 1991). Classification of Campylobacter has always been problematic, because the species are relatively inert in most traditional biochemical tests, and therefore relationships between species were often uncertain. As a result of extensive taxonomic revisions based on macromolecular studies, the genus Campylobacter is currently considered to comprise eleven species (Vandamme \& De Ley, 1991). Several, notably Campylobacter jejuni, are recognized to be pathogenic for man. There is increasing interest in more accurate definition of the microbial ecology, phenotypic subtyping and pathogenicity of campylobacters. This is especially so since epidemiological evidence now identifies this bacterial genus as one of the primary agents of infectious gastroenteritis in humans in

* Author for correspondence. Tel. 0814400 ext. 3738; fax 081200 7874. developed countries. For example, the annual total for human Campylobacter infections was more than 34000 in 1990, a figure in excess of total Salmonella infections (Healing et al., 1992).

The natural habitat of most Campylobacter species is the intestinal tract of warm-blooded animals, including birds (Park et al., 1991), and bacteria are transmitted to man from animals either by direct contact or indirectly by food, milk or water. Campylobacterosis in man is largely a foodborne infection in which foods of animal origin, particularly poultry, play an important role (Franco, 1988). It is widely assumed that most infections occur as a result of consuming inadequately prepared food. Campylobacter spp. are also found in raw milk, river water and sewage, which are all possible sources of infection.

While studying detection of $C$. upsaliensis in diarrhoeic dogs and cats on selective cefoperazone-containing medium, a group of unidentified Campylobacter strains was observed growing on the same medium. These isolates (6 of 72 catalase-negative thermophilic isolates) gave the same results as $C$. upsaliensis in classical phenotypic tests, but did not react positively with $C$. 
upsaliensis DNA in DNA-DNA dot hybridization assays (Burnens \& Nicolet, 1992). During an epidemiological study of Campylobacter carriage among household pets, Campylobacter isolates of the same type were again isolated, and formed the most common Campylobacter type recovered from cats $(48 \%$ of all feline isolates). This isolate type was much rarer in dogs; only $2 \%$ of canine Campylobacter isolates belonged to the group. For both cats and dogs, strains of the group were found more frequently among healthy animals than in animals suffering from gastroenteritis. In a study comparing the efficiency of recovery media, $38 \%$ of these isolates were recovered exclusively on cefoperazone-vancomycin-amphotericin B agar, and $10 \%$ exclusively on horse blood agar by filtration. The remaining $52 \%$ of isolates were recovered on both media (Burnens et al., 1992). For the purposes of the present study the isolates were termed the ' $\mathrm{CH}$ ' (Swiss) group.

A designated type strain and other exemplars of the $\mathrm{CH}$ group were subjected to detailed phenotypic and molecular analysis. In this report we present evidence that they represent a previously undescribed thermophilic Campylobacter species, which we have named Campylobacter helveticus, after its country of first isolation. We have, furthermore, cloned a recombinant DNA probe which provides discriminatory speciesspecific identification of the new species.

\section{Methods}

Bacterial strains. Bacterial strains and type strains used in this study are listed in Table 1. Campylobacter and Arcobacter spp. were cultured on $5 \%(\mathrm{v} / \mathrm{v})$ horse blood agar plates in a Variable Atmosphere Incubator (Don Whitley Scientific). This maintained a microaerobic atmosphere of $5 \% \mathrm{O}_{2} / 5 \% \mathrm{CO}_{2} / 2 \% \mathrm{H}_{2} / 88 \% \mathrm{~N}_{2}$ (by vol.) at $37^{\circ} \mathrm{C}$.

Phenotypic characterization. The phenotype of the isolates was determined by employing the methods and media recommended by $\mathrm{On}$ $\&$ Holmes (1991 $a, b, 1992)$. Additional tests were performed as follows: production of extracellular deoxyribonuclease (DNAase) was determined by the method of Lior \& Patel (1987). Growth on potato starch medium was determined using the medium of Cowan (1974); an inoculum of approximately $10^{6}$ c.f.u. $\mathrm{ml}^{-1}$ (On \& Holmes, 1991 a) was used and plates were incubated for $3 \mathrm{~d}$ in a microaerobic atmosphere at $37^{\circ} \mathrm{C}$. Colonial morphology of the $\mathrm{CH}$ group isolates was recorded after $3 \mathrm{~d}$ microaerobic incubation on $5 \%(\mathrm{v} / \mathrm{v})$ horse blood agar at $37^{\circ} \mathrm{C}$. All tests were performed in triplicate, on separate occasions and with freshly prepared media. Phenotypes of the $\mathrm{CH}$ group and other campylobacters are summarized in Table 2, which was compiled from NCTC and literature data (Tanner et al., 1981, 1984; Skirrow, 1990).

Protein electrophoresis. Protein samples were prepared and run on SDS-PAGE gels as described previously (Costas, 1992). The stained protein patterns in the dried gels were scanned using a laser densitometer. Analysis and computation of similarity were as described by Costas (1992). The analysis was based on the background pattern after removal of the major protein bands, as shown to be necessary for species differentiation in Campylobacter (Costas, 1992).
Nucleic acid techniques. Total DNA was prepared from representative species constituting rRNA superfamily VI (Vandamme et al., 1991), according to the protocol of Wilson (1987) for genomic Southern blots, cloning and hybridization analysis; or according to the protocol of Owen \& Borman (1987) for $\mathrm{mol} \% \mathrm{G}+\mathrm{C}$ content determination. DNA was prepared from all strains except for isolate A722/91, which proved refractory to isolation of intact genomic DNA, and was therefore omitted from some analyses. Aliquots $(2.5 \mu \mathrm{g})$ of DNA were digested to completion with restriction enzymes (PstI, PvuII, HindIII or $B g / \mathrm{II}$ ), electrophoresed for $16 \mathrm{~h}$ at $30 \mathrm{~V}$ in $0.8 \%$ agarose slab gels and vacuum-blotted onto Hybond $\mathrm{N}$ nylon membrane filters (Amersham). DNA probes were labelled by random-priming with biotin-16-dUTP or ${ }^{35} \mathrm{~S}$-dATP. Membrane filters were baked at $80^{\circ} \mathrm{C}$ for $2 \mathrm{~h}$, wetted with $5 \times$ SSC, prehybridized $(4 \mathrm{~h})$, and hybridized $(16 \mathrm{~h})$ at $45^{\circ} \mathrm{C}$. Prehybridization mix consisted of $5 \mathrm{xSSC}[1 \times$ SSC (standard saline citrate) is $150 \mathrm{~mm}$-sodium chloride, $15 \mathrm{~mm}$-trisodium citrate] containing $50 \%(\mathrm{v} / \mathrm{v}$ ) formamide, $25 \mathrm{~mm}$-sodium phosphate buffer ( $\mathrm{pH} 6.5$ ), $0 \cdot 1 \%(\mathrm{w} / \mathrm{v})$ Ficoll, $0 \cdot 1 \%(\mathrm{w} / \mathrm{v})$ polyvinylpyrrolidone, $0 \cdot 1 \%(\mathrm{w} / \mathrm{v})$ bovine serum albumin, $0.5 \%(\mathrm{w} / \mathrm{v})$ sodium dodecyl sulphate (SDS) and $500 \mu \mathrm{g}$ denatured herring sperm DNA ml${ }^{-1}$. Hybridization mix, additionally, contained $5 \%(\mathrm{w} / \mathrm{v})$ dextran sulphate. Hybridized filters were washed in $0.16 \times \mathrm{SSC}$ as a final stringent wash $\left(50^{\circ} \mathrm{C}\right)$. Colour development for biotinylated probe hybridizations was done with the Blu-Gene system (Gibco-BRL). Hybridizations with ${ }^{35}$ S-labelled probes were carried out in the same way and filters were washed in $2 \times \mathrm{SSC}, 0.1 \%$ SDS (medium stringency) or $0.2 \times \mathrm{SSC}, 0.1 \% \mathrm{SDS}$ (high stringency) at $65^{\circ} \mathrm{C}$. Membranes were exposed to Hyperpaper (Amersham) for $16 \mathrm{~h}$ for autoradiography.

DNA-DNA slot-blot hybridization was performed on Hybond N nylon membrane (Amersham) using a vacuum-blotting apparatus (Hybri-slot, Bethesda Research Laboratories). A $200 \mathrm{ng}$ aliquot of genomic DNA, prepared as described above, was loaded in each slot. DNA was fixed to filters by baking for $2 \mathrm{~h}$ at $80^{\circ} \mathrm{C}$. Biotinylated probe DNA was prepared from genomic DNA of NCTC 12470 as follows: DNA was digested with HindIII and biotin-16-dUTP was incorporated into termini with Klenow DNA polymerase in a standard protocol for end-labelling (Sambrook et al., 1989). Each hybridization contained $1 \mu \mathrm{g}$ of labelled probe DNA. Prehybridization, hybridization and detection were as described above for genomic Southern blots. The developed slot-blots on the nylon membrane were scanned using an LKB Ultroscan XL laser densitometer. Absorbance was recorded at $160 \mu \mathrm{m}$ intervals. The absorbance range was set from 1.8 to 4.0 (full scale). A rectangular line beam $(800 \mu \mathrm{m} \times 50 \mu \mathrm{m})$ was used to scan each slot three times (with no overlap in scan positives), resulting in a multiple track scan of $2.4 \mathrm{~mm}$ width. Multiple scanning was employed to reduce the effect of inconsistencies which may be encountered across each slot. The mean absorbance of the area scanned was recorded. Since the slots are of equal thickness, peak heights are directly proportional to the peak areas. Thus peak heights were used to calculate relative homology values. The $100 \%$ value (maximum peak height) was produced by self-hybridization of the probe with NCTC 12470 DNA (see Fig. 2).

The DNA base composition ( $\mathrm{mol} \% \mathrm{G}+\mathrm{C}$ content) was estimated from the thermal denaturation temperature $\left(T_{\mathrm{m}}\right)$, which was determined in triplicate in one-third strength SSC (Owen \& Pitcher, 1985). The base composition was expressed relative to a chemically determined value of $51 \cdot 1 \mathrm{~mol} \% \mathrm{G}+\mathrm{C}$ for Escherichia coli NCTC 9001 .

The general purpose 'ribotyping' probe was synthesized from $C$. jejuni subsp. jejuni NCTC 11351 by reverse transcription as previously described (Pitcher et al., 1987). A mini-library of NCTC 12470 genomic DNA was constructed by standard methods by cloning random HindIII fragments into the vector pUC19 (Yanisch-Perron et al., 1985). Cloned fragments were excised, electroeluted and randomprimer-labelled for hybridization experiments. 
Table 1. Bacterial strains

\begin{tabular}{|c|c|c|c|}
\hline Bacteria & Strain no. & Reference/comment & Source \\
\hline $\begin{array}{l}\text { Campylobacter } \\
\text { C. fetus subsp. fetus } \\
\text { C. fetus subsp. venerealis } \\
\text { C. coli } \\
\text { C. jejuni subsp. jejuni } \\
\text { C. jejuni subsp. doylei } \\
\text { C. lari } \\
\text { C. upsaliensis } \\
\text { C. upsaliensis } \\
\text { C. hyointestinalis } \\
\text { C. mucosalis } \\
\text { C. sputorum biovar faecalis } \\
\text { C. sputorum biovar bubulus } \\
\text { C. sputorum biovar sputorum } \\
\text { C. concisus } \\
\text { C. curvus } \\
\text { C. rectus } \\
\text { 'CH group' }\end{array}$ & $\begin{array}{l}\text { NCTC } 10842 \\
\text { NCTC } 10354 \\
\text { NCTC } 11366 \\
\text { NCTC } 11351 \\
\text { NCTC } 11951 \\
\text { NCTC } 11352 \\
\text { NCTC } 11540 \\
\text { NCTC } 11541 \\
\text { NCTC } 11608 \\
\text { NCTC } 11000 \\
\text { NCTC } 11415 \\
\text { NCTC } 11367 \\
\text { NCTC } 11528 \\
\text { NCTC } 11485 \\
\text { NCTC } 11649 \\
\text { NCTC } 11489 \\
\text { NCTC } 12470 \\
\text { NCTC } 12471 \\
\text { NCTC } 12472 \\
\text { NCTC } 12473 \\
\text { A722/91* } \\
\text { A723/91* } \\
\text { A724/91* } \\
\text { A725/91* } \\
\text { A726/91* } \\
\text { A727/91* }\end{array}$ & $\begin{array}{l}\text { Type strain } \\
\text { Type strain } \\
\text { Type strain } \\
\text { Type strain } \\
\text { Type strain } \\
\text { Type strain } \\
\text { Reference strain } \\
\text { Reference strain } \\
\text { Type strain } \\
\text { Type strain } \\
\text { Reference strain } \\
\text { Reference strain } \\
\text { Reference strain } \\
\text { Type strain } \\
\text { Type strain } \\
\text { Type strain } \\
=\text { D5248* } \\
=\text { E1202* } \\
=\text { E1208* } \\
=\text { E1218* }\end{array}$ & $\begin{array}{l}\text { Ovine } \\
\text { Bovine } \\
\text { Porcine } \\
\text { Bovine } \\
\text { Human infant } \\
\text { Avian (herring gull) } \\
\text { Canine } \\
\text { Canine } \\
\text { Porcine } \\
\text { Porcine } \\
\text { Ovine } \\
\text { Bovine } \\
\text { Human } \\
\text { Human } \\
\text { Human } \\
\text { Human } \\
\text { Feline } \\
\text { Feline } \\
\text { Feline } \\
\text { Feline } \\
\text { Feline } \\
\text { Feline } \\
\text { Feline } \\
\text { Feline } \\
\text { Feline } \\
\text { Feline }\end{array}$ \\
\hline $\begin{array}{l}\text { Arcobacter } \\
\text { A. cryaerophilus } \\
\text { A. butzleri } \\
\text { A. nitrofigilis }\end{array}$ & $\begin{array}{l}\text { NCTC } 11885 \\
\text { NCTC } 12400 \\
\text { NCTC } 12251\end{array}$ & $\begin{array}{l}\text { Type strain } \\
\text { Type strain }\end{array}$ & $\begin{array}{l}\text { Bovine } \\
\text { Water } \\
\text { Plant }\end{array}$ \\
\hline $\begin{array}{l}\text { Helicobacter } \\
\text { H. pylori } \\
\text { H. felis } \\
\text { H. mustelae } \\
\text { 'H. acinonyx' } \\
\text { H. cinaedi } \\
\text { H. fennelliae } \\
\text { H. nemestrinae }\end{array}$ & $\begin{array}{l}\text { NCTC } 11637 \\
\text { NCTC } 12436 \\
\text { NCTC } 12435 \\
\text { NCTC } 12686 \\
\text { NCTC } 12432 \\
\text { NCTC } 11612 \\
\text { NCTC } 12491\end{array}$ & $\begin{array}{l}\text { Type strain } \\
\text { Type strain } \\
\text { Type strain } \\
\text { Reference strain } \\
\text { Reference strain } \\
\text { Type strain }\end{array}$ & $\begin{array}{l}\text { Human } \\
\text { Feline } \\
\text { Ferret } \\
\text { Cheetah } \\
\text { Human } \\
\text { Human } \\
\text { Monkey }\end{array}$ \\
\hline $\begin{array}{l}\text { 'Flexispira rappini' } \\
\text { Wolinella succinogenes }\end{array}$ & $\begin{array}{l}\text { NCTC } 12461 \\
\text { NCTC } 11488\end{array}$ & $\begin{array}{l}\text { Type strain } \\
\text { Type strain }\end{array}$ & $\begin{array}{l}\text { Human } \\
\text { Bovine }\end{array}$ \\
\hline $\begin{array}{l}\text { Bacteroides ureolyticus } \\
\text { Escherichia coli } \\
\text { Salmonella typhimurium }\end{array}$ & $\begin{array}{l}\text { NCTC } 10941 \\
\text { FM15 } \\
\text { NCTC 9001 } \\
\text { NCTC } 12416\end{array}$ & $\begin{array}{l}\text { Type strain } \\
\text { Dowling et al. (1987) } \\
\text { Type strain } \\
\text { Type strain, subsp. } 1\end{array}$ & $\begin{array}{l}\text { Human } \\
- \\
- \\
-\end{array}$ \\
\hline
\end{tabular}

* Strains were from a set of isolates made from diarrhoeic and healthy cats by Burnens et al. (1992).

Electron microscopy. Cells were taken from a $48 \mathrm{~h}$ culture on blood agar, and resuspended carefully in $0.5 \mathrm{ml}$ distilled water to make a turbid suspension. Formaldehyde was added to $2 \%(\mathrm{v} / \mathrm{v})$. Thereafter cells were gently resuspended in $0.05 \%$ bovine plasma albumin for spreading, negatively stained with $1 \%(\mathrm{w} / \mathrm{v})$ phosphotungstic acid and examined at a magnification of 11000 in a JEOL 1200 EX electron microscope at $80 \mathrm{kV}$.

\section{Results}

\section{Phenotypic characterization}

In total, 39 phenotypic tests were performed on 10 strains of the $\mathrm{CH}$ group. Tests which were reproducibly positive in triplicate for all strains in the $\mathrm{CH}$ group were the production of oxidase, reduction of nitrate to nitrite, hydrolysis of indoxyl acetate, growth at $37^{\circ} \mathrm{C}$, at $42^{\circ} \mathrm{C}$, and on Campylobacter charcoal-desoxycholate (CCD, unsupplemented Preston base) medium, on $1 \%(\mathrm{w} / \mathrm{v})$ bile medium, and on 5-fluorouracil (5-FU) $\left(100 \mu \mathrm{g} \mathrm{ml}{ }^{-1}\right)$ media. Tests which were consistently negative for all $\mathrm{CH}$ group strains were the production of catalase, urease, DNAase, and alkaline phosphatase, the reduction of selenite and triphenyltetrazolium chloride (TTC), and production of hydrogen sulphide from triple sugar iron (TSI) medium. The $\mathrm{CH}$ group strains did not grow at room temperature $\left(18-22^{\circ} \mathrm{C}\right)$, at $25^{\circ} \mathrm{C}$, in aerobic or 


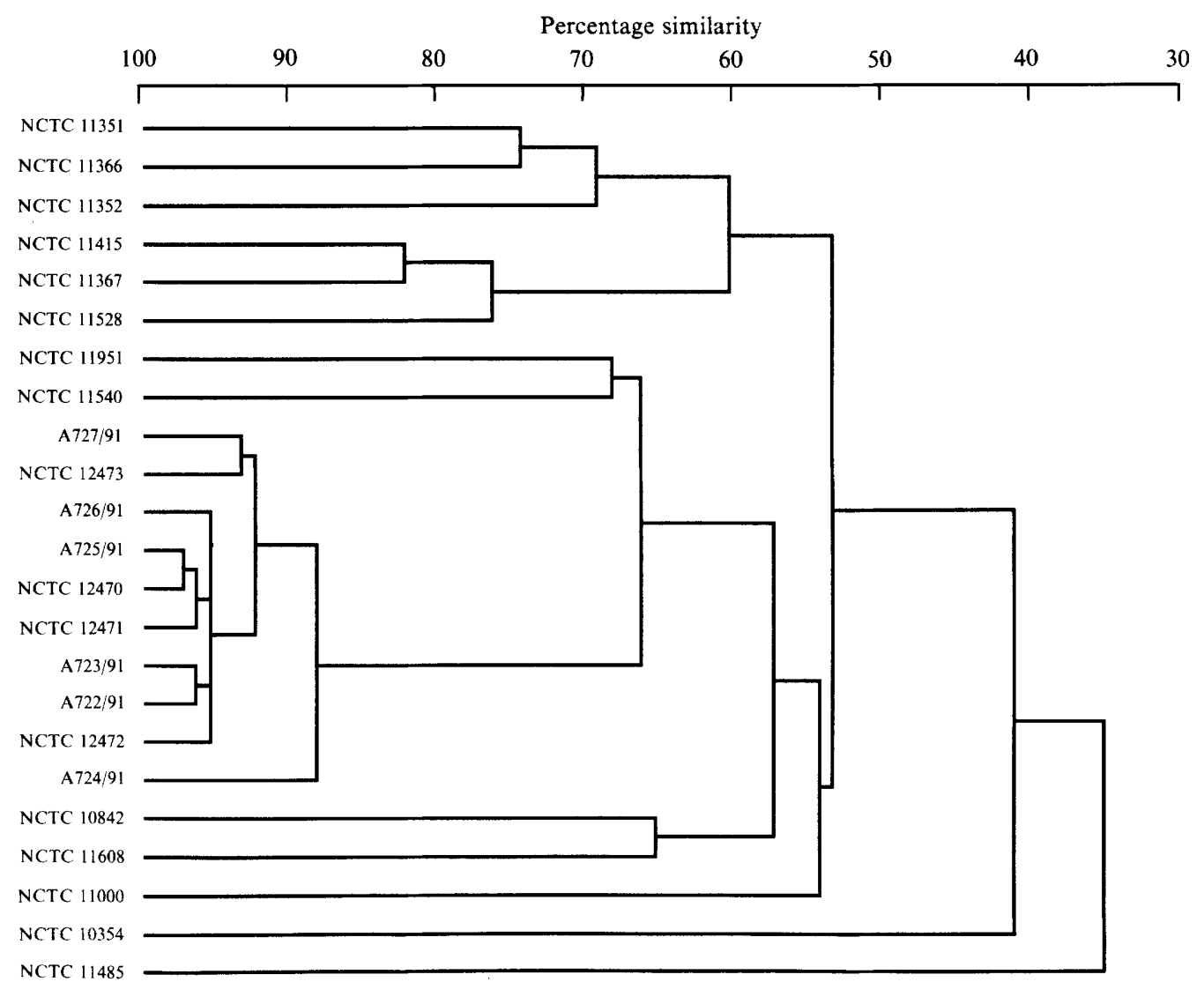

Fig. 1. Dendrogram of the numerical analysis based on the background protein pattern of strains. The vertical axis shows $C$. helveticus and the type strains of other Campylobacter species and subspecies as listed in Table 1. The numbers on the horizontal axis indicate the percentage similarities as determined by the Pearson product-moment correlation coefficient and UPGMA clustering.

anaerobic conditions, on minimal and potato starch media, on $0.1 \%$ trimethylamine $N$-oxide (TMAO) medium under conditions of anaerobiosis, or on media containing $0.04 \%$ TTC, $0.1 \%$ potassium permanganate, $0.02 \%$ sodium arsenite, nalidixic acid $\left(32 \mu \mathrm{g} \mathrm{ml}^{-1}\right)$, cephalothin $\left(32 \mu \mathrm{g} \mathrm{ml}^{-1}\right)$, carbenicillin $\left(32 \mu \mathrm{g} \mathrm{ml}^{-1}\right)$ or metronidazole $\left(4 \mu \mathrm{g} \mathrm{ml}^{-1}\right)$ (in the latter two tests where nutrient agar was used as the basal medium). Variable results were obtained with growth on nutrient agar, and on media containing $2 \%(\mathrm{w} / \mathrm{v}) \mathrm{NaCl}, 1 \%(\mathrm{w} / \mathrm{v})$ glycine, carbenicillin $\left(32 \mu \mathrm{g} \mathrm{ml}^{-1}\right)$ and cefoperazone $(64 \mu \mathrm{g}$ $\mathrm{ml}^{-1}$ ) where blood agar was employed as the basal medium. Growth at $30^{\circ} \mathrm{C}$, on buffered charcoal yeast (BCY) medium and on metronidazole $\left(4 \mu \mathrm{g} \mathrm{ml}{ }^{-1}\right)$ medium (where blood agar served as the base) were not found to be reliable tests for characterizing this group.

$\mathrm{CH}$ group strains exhibited a colonial morphology which was characteristic and useful in distinguishing them from other thermophilic campylobacters, including C. upsaliensis. Colonies were flat and smooth, with a watery spreading appearance on blood agar. In addition, colonies were faintly tinted with a blue-green hue. A list of characteristics useful in discriminating the $\mathrm{CH}$ group from other Campylobacter species is given in Table 2.

\section{Whole-cell protein analysis}

One-dimensional SDS-PAGE of whole-cell protein extracts of $\mathrm{CH}$ group strains produced $\geq 40$ discrete bands. Differences between the strains were evident principally in a major protein band in the $40-45 \mathrm{kDa}$ region. Numerical analysis of the background PAGE-protein patterns, based on the determination of the correlation coefficient and UPGMA clustering, indicated that at the $88 \%$ similarity level the $10 \mathrm{CH}$ group strains clustered together in a single phenon. The patterns of $\mathrm{CH}$ group strains were clearly distinguishable from those of the type strains of all other Campylobacter species, subspecies and biovars examined. A dendrogram representing the comparative analysis of protein patterns of the $\mathrm{CH}$ group with those of the other Campylobacter species is shown in Fig. 1. Within the $\mathrm{CH}$ group the background protein pattern was homogeneous but there was a degree of heterogeneity with respect to the molecular mass of a 


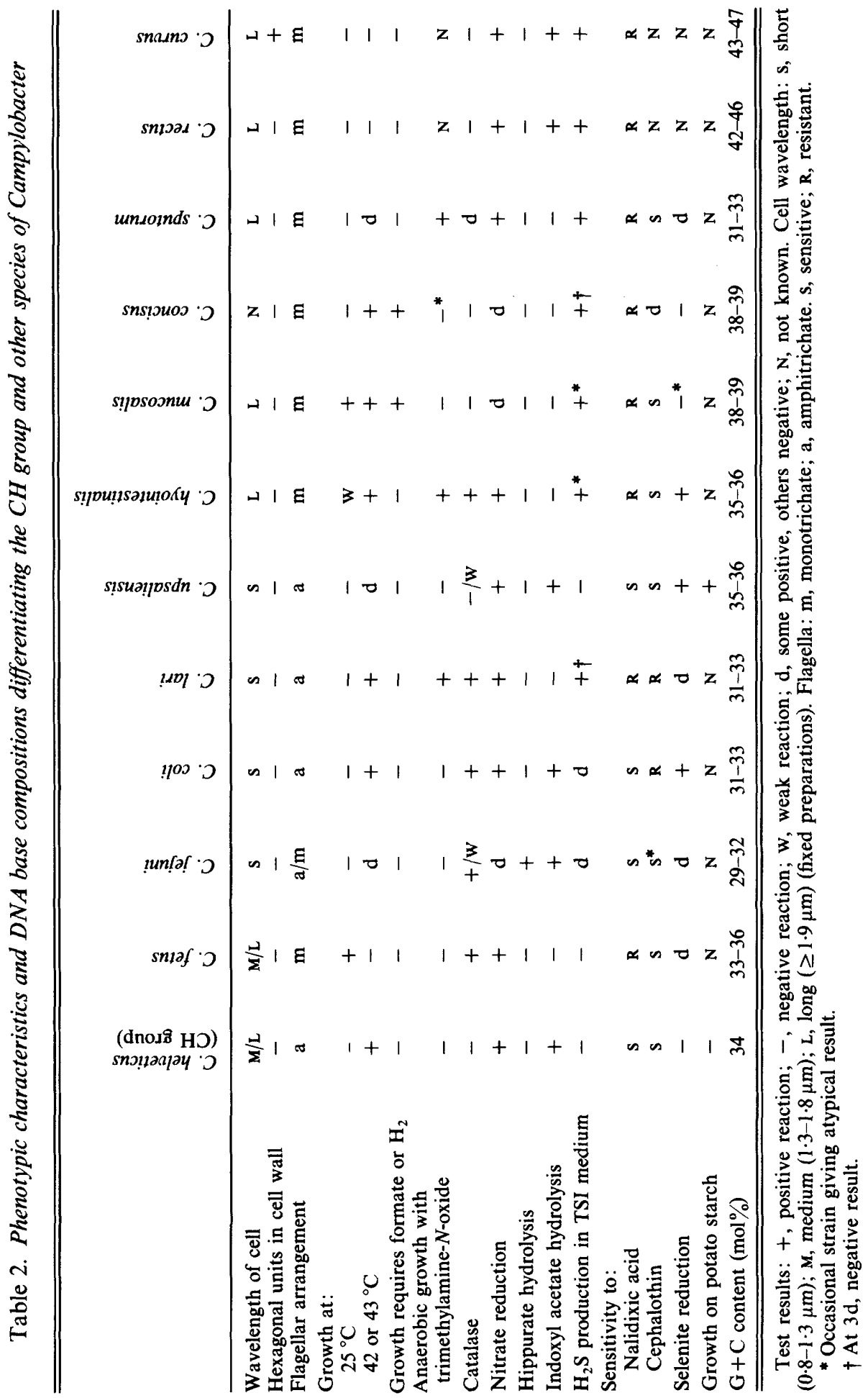




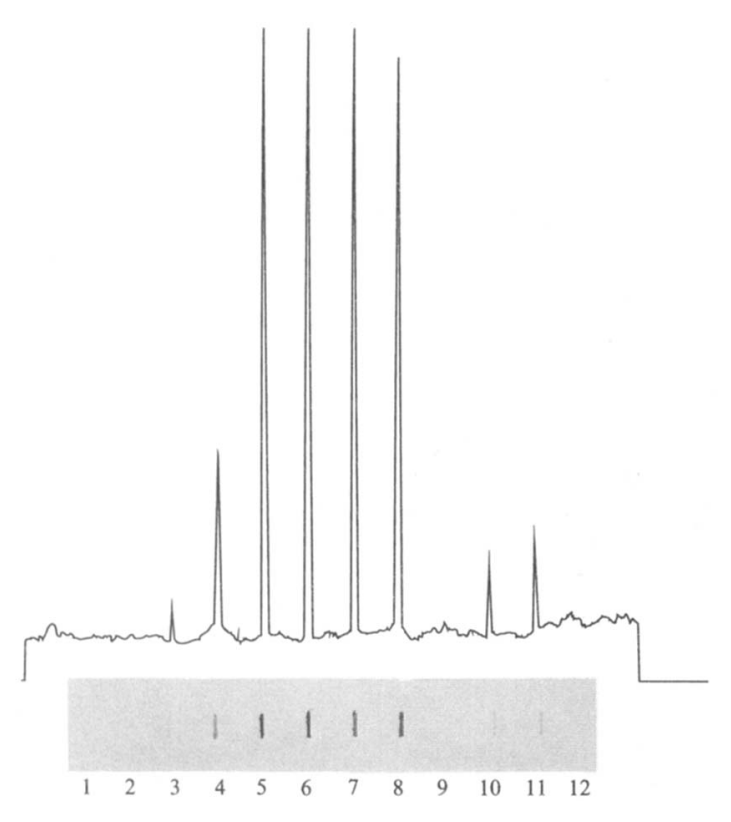

Fig. 2. Genetic relatedness of the $\mathrm{CH}$ group and other Campylobacter species. Slot-blot hybridization was performed using biotinylated probe DNA from the $\mathrm{CH}$ group strain NCTC 12470. Slot 1 contained no DNA ( $\mathrm{H}_{2} \mathrm{O}$ control). Slots $2-12$ respectively contained DNA of : 2 , C. jejuni subsp. jejuni NCTC $11351 ; 3, C$. jejuni subsp. doylei NCTC $11951 ; 4, C$. upsaliensis NCTC $11540 ; 5$, NCTC 12470; 6, NCTC $12471 ; 7$, NCTC $12472 ; 8$, NCTC 12473; 9, C. fetus subsp. fetus NCTC $10842 ; 10$, C. coli NCTC $11366 ; 11$, C. lari NCTC 11352; 12, Salmonella typhimurium.

major protein band in the $40-45 \mathrm{kDa}$ region. Indeed, in this area of the gel five distinct molecular masses could be distinguished visually among different $\mathrm{CH}$ group strains.

\section{DNA-DNA hybridization}

Slot-blot hybridization was carried out to determine overall genetic relatedness between the $\mathrm{CH}$ group and representative species of rRNA superfamily VI (Vandamme et al., 1991). When total DNA of $\mathrm{CH}$ strain NCTC 12470 was used as a probe, there was no detectable homology with DNA of $C$. jejuni subsp. jejuni, C. fetus subsp. fetus or Salmonella typhimurium (Fig. 2, slots 2,9 and 12 , respectively). In the same way, there was no homology with DNA of $C$. concisus, $C$. hyointestinalis, $C$. mucosalis, $C$. sputorum, C. rectus, $C$. curvus, A. cryaerophilus, A. butzleri, A. nitrofigilis, 'Flexispira rappini', Wolinella succinogenes, Bacteroides ureolyticus, Helicobacter pylori, $H$. felis, $H$. mustelae, $H$. cinaedi, $H$. fennelliae, $H$. nemestrinae or ' $H$. acinonyx' (data not shown). A low degree of partial DNA homology ( $<25 \%$ ) was observed with $C$. jejuni subsp. doylei, C. coli and C. lari (Fig. 2, slots 3, 10 and 11, respectively), but a higher $(35 \%)$ homology level was detected with C. upsaliensis NCTC 11541 (Fig. 2, slots 5 vs 4$)$.

\section{Ribosomal RNA (rrn) gene profiles}

DNA of the $\mathrm{CH}$ group and of type strains of other Campylobacter species was digested with PvuII (Fig.3a), PstI or BgIII (data not shown) for genomic Southern blots, and hybridized with a general-purpose rRNA gene probe, reverse transcribed from $16 \mathrm{~S}$ and 23S rRNA of $C$. jejuni. Irrespective of the enzyme used, all (9/9) tested strains of the $\mathrm{CH}$ group had similar or identical ribopatterns, unique among those of the type strains of the Campylobacter species examined. For example, no $r r$-homologous PstI fragments of the $\mathrm{CH}$ group strains (Fig.3a, lanes 11-19) were common to those of $C$. upsaliensis (Fig.3a, lane 6), its nearest relative by total DNA hybridization, or to those of any other Campylobacter spp.

\section{DNA base composition}

The DNA base composition of NCTC 12470, NCTC 12471, NCTC 12472 and NCTC 12473 was determined as $34 \mathrm{~mol} \% \mathrm{G}+\mathrm{C}$.

\section{Development of a cloned probe specific for $\mathrm{CH}$ group strains}

Recombinant DNA clones (random HindIII fragments cloned from NCTC 12470 into pUC19) were evaluated for homology within the $\mathrm{CH}$ group strains, and with all the Campylobacter type strains in Table 1. Following medium-stringency washing of the membrane filter $(2 \times \mathrm{SSC}, 0 \cdot 1 \%$ SDS), none of three tested probes exhibited any homology with the reference strain DNAs other than a minor degree of homology with DNA of $C$. upsaliensis. Two of the three probes tested detected some degree of restriction fragment length polymorphism in PvuII or PstI genomic digests of individual strains of the $\mathrm{CH}$ group. A third probe examined, termed pCH1 (see Fig. $3 b$ ) was a $0.8 \mathrm{kbp}$ HindIII fragment, and exhibited no polymorphism within the $\mathrm{CH}$ group (all strains carried a HindIII fragment of $0.8 \mathrm{kbp}$, a PstI fragment of $9.3 \mathrm{kbp}$ and a PvulI fragment of $>15 \mathrm{kbp}$ ). When the stringency of the final filter wash was increased $(0.2 \times \mathrm{SSC}, 0.1 \% \mathrm{SDS})$ this probe also reacted uniquely with all $\mathrm{CH}$ group strains tested, and not with any other Campylobacter species. 

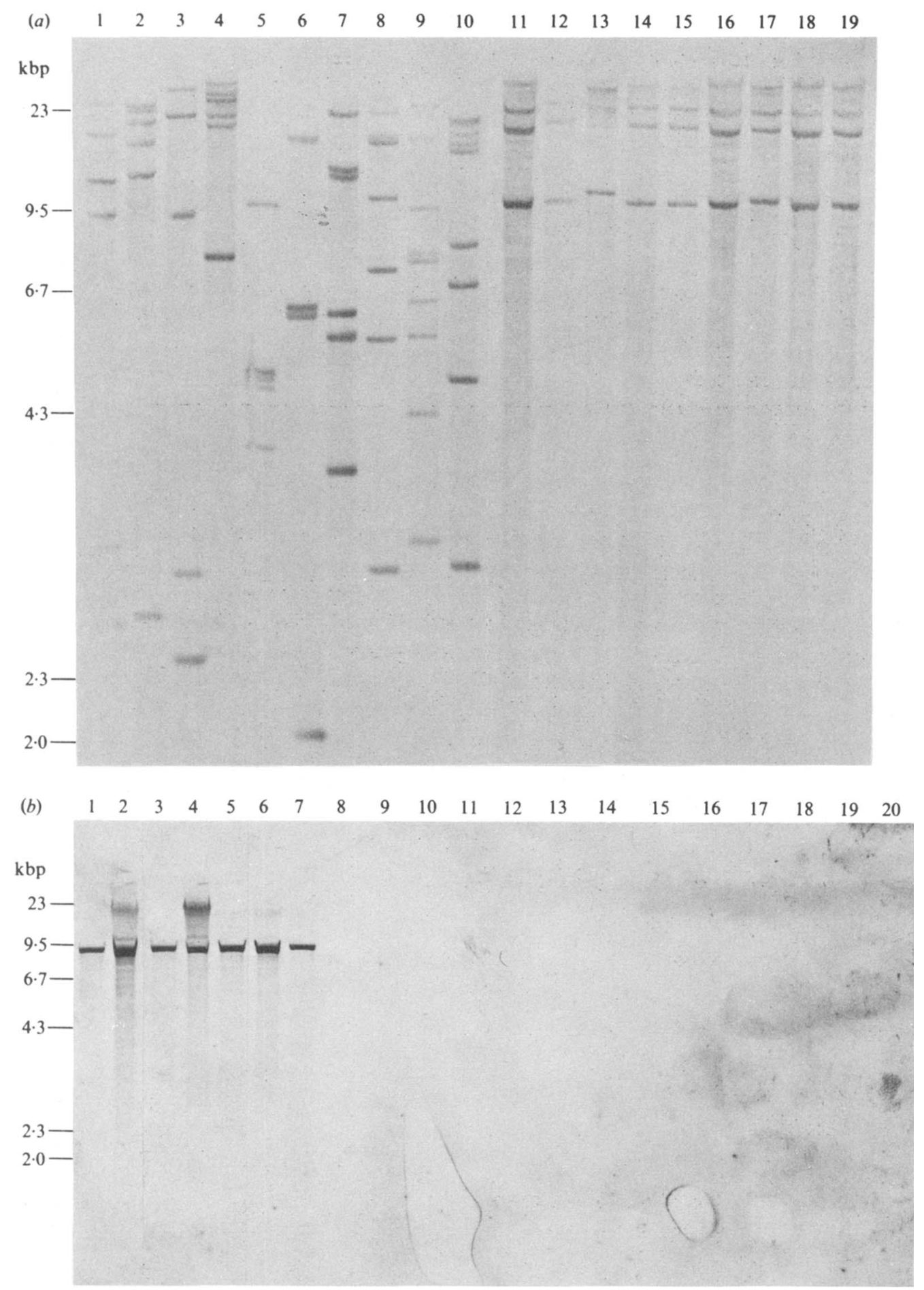

Fig. 3 (a). Ribosomal RNA gene profiles of $\mathrm{CH}$ group strains and Campylobacter species type strains. Genomic DNA was digested with PvuII and a Southern blot was hybridized with the general-purpose ribotyping probe, corresponding to $16+23 \mathrm{~S}$ rRNA. Tracks contained: $1, C$. fetus subsp. fetus NCTC 10842; 2, C. coli NCTC $11366 ; 3$, C. jejuni subsp. jejuni NCTC 11351; 4, C. jejuni subsp. doylei NCTC $11951 ; 5$, C. lari NCTC 11352; 6, C. upsaliensis NCTC $11541 ; 7$, C. upsaliensis NCTC 11540; 8, C. concisus NCTC $11485 ; 9$, C. hyointestinalis NCTC 11608; 10, C. sputorum biovar. bubulus NCTC 11367; 11, NCTC 12470; 12, NCTC 12471; 13, NCTC 12472; 14, NCTC 12473; 15, A725/91; 16, A726/91; 17, A724/91; 18, A722/91; 19, A723/91. (b) Homology of pCH1 to CH group strains and Campylobacter/Arcobacter species type strains. The $0.8 \mathrm{kbp}$ HindIII fragment cloned in pCH1 was labelled with ${ }^{35} \mathrm{~S}-\mathrm{ATP}$ and hybridized with genomic DNA digested with PstI. Tracks 1-7 contained seven CH strains, respectively: 1, NCTC 12470; 2, NCTC 12471; 3, NCTC 12472; 4, NCTC 12473; 5, A722/91; 6, A723/91; 7, A724/91. Tracks 8-20 contained respectively: 8, A. butzleri NCTC $12400 ; 9$, A. cryaerophilus NCTC $11885 ; 10, C$. sputorum biovar. bubulus NCTC $11367 ; 11, C$. mucosalis NCTC 11000; $12, C$. hyointestinalis NCTC 11608; 13, C. concisus NCTC 11485; 14, C. upsaliensis NCTC 11541; 15, C. upsaliensis NCTC 11540; 16, C. lari NCTC 11352; 17, C. jejuni subsp. doylei NCTC 11951; 18, C. jejuni subsp. jejuni NCTC 11351; 19, C. coli NCTC 11366; 20, C. fetus subsp. fetus NCTC 10842. No homology was detected with C. curvus or C. rectus (data not shown). 


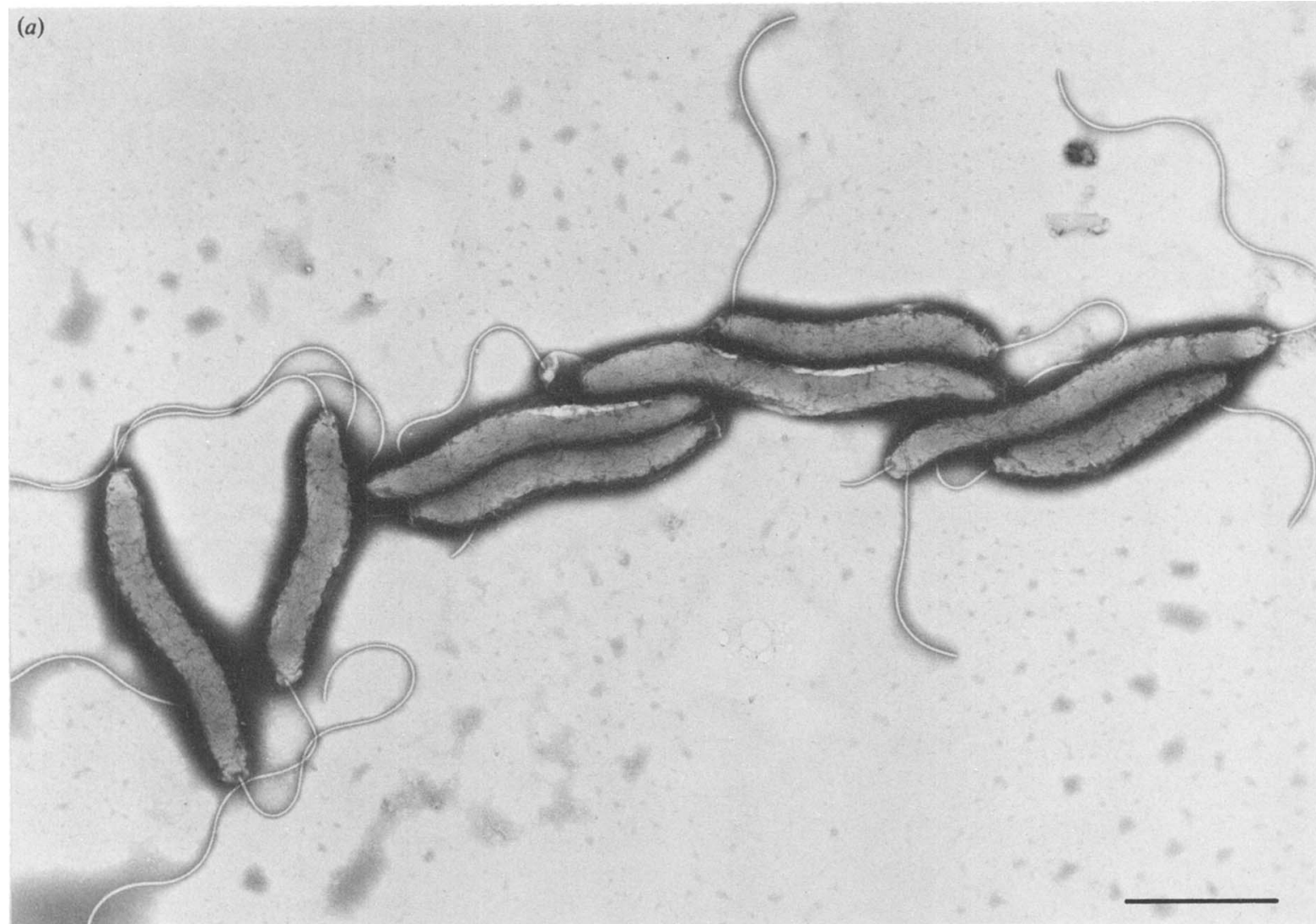

(b)

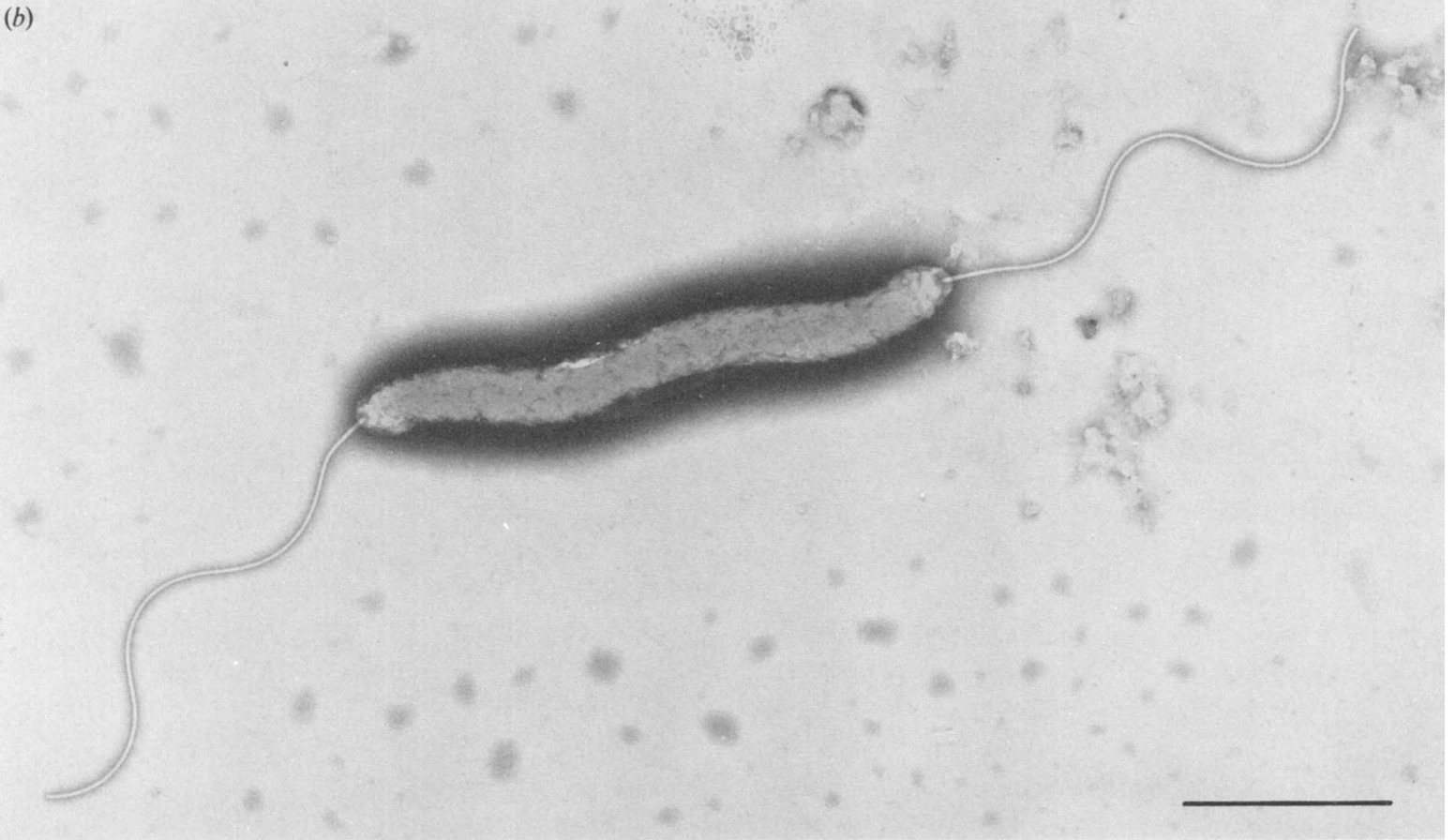

Fig. 4. (a) Electron micrograph of $C$. helveticus culture. Cells vary in size from 1.5 to $3.0 \mu \mathrm{m}$, and exhibit a slight spiral curvature. Bar, $1 \mu \mathrm{m}$. (b) Electron micrograph of a single cell of $C$. helveticus NCTC 12470. The organism carries single bipolar unsheathed flagella, inserted into a regular shaped basal body. Bar, $1 \mu \mathrm{m}$. 


\section{Electron microscope examination of whole cells}

As seen in Fig. 4, cells were slender, regular and exhibited a slight spiral curvature. All cells carried single amphitrichate polar flagella. Flagella were unsheathed.

\section{Discussion}

In the present report we provide the $\mathrm{mol} \% \mathrm{G}+\mathrm{C}$ content and several major lines of evidence that the $\mathrm{CH}$ group of Campylobacter found in domestic cats and dogs represents a new and previously undescribed thermophilic species, for which we propose the name $C$. helveticus. The bacteriological characteristics and the $34 \mathrm{~mol} \% \mathrm{G}+\mathrm{C}$ content are typical of the genus Campylobacter, as is the whole-cell morphology and the presence of unsheathed flagella observed in the electron microscope. Furthermore, no relative DNA homology was detected with any species belonging to rRNA superfamily VI (Vandamme et al., 1991) except for the thermophilic Campylobacter species, notably $C$. upsaliensis. Nonetheless, the $\mathrm{CH}$ group has unique phenotypic characteristics, whole-cell protein profiles and ribosomal RNA gene profiles, and its DNA homologies are distinct from the described Campylobacter species. We were also able to clone a species-specific recombinant DNA probe.

The colonial morphology of $C$. helveticus on blood agar (flat, translucent, adherent colonies about $0.5 \mathrm{~mm}$ in diameter) is distinct from that of all named Campylobacter species. $C$. helveticus is distinguished bacteriologically from the thermophilic species $C$. coli, $C$. jejuni and $C$. lari, since it is catalase negative. It is differentiated from the catalase-negative species (other than $C$. upsaliensis) since it is indoxyl acetate positive. Analysis of electrophoretic protein patterns indicated that $C$. helveticus forms a homogeneous cluster of strains whose nearest neighbours are $C$. upsaliensis and $C$. jejuni subsp. doylei, which are linked to $C$. helveticus at the $66.5 \%$ similarity level. All other taxa examined clustered at an even lower level. These percentage similarity values concur with the $35 \%$ relative DNA homology of $C$. helveticus with $C$. upsaliensis and demonstrate that $C$. helveticus is a taxonomic entity distinct from any other Campylobacter species. This is further substantiated by the intra-group homogeneity and unique homology profile of the 16S and 23S ribosomal RNA genes.

Most conventional phenotypic characteristics of $C$. helveticus showed a considerable degree of similarity to C. upsaliensis, and our analysis of relative (interspecific) DNA homology also indicated that $C$. helveticus is more closely related to this than to any other Campylobacter species. The level of homology observed with $C$. upsaliensis $(35 \%)$ was high when considered relative to the interspecific values described for the genus Campylobacter. The most closely related Campylobacter species, $C$. jejuni and $C$. coli, exhibit only up to $40 \%$ homology. Between these and/or between other species, values of $20 \%$ or less are typical (Owen, 1983; Roop et al., 1984; Owen \& Dawson, 1986). The densitometric method of calculating relative DNA homology as used here is likely to be as significant as conventional (S1 nuclease and radioactively labelled DNA) methods at low levels of DNA homology. Lee \& McGee (1989) have demonstrated that the signal intensity developed by nonisotopic methods on Southern blots is linear with time and the quantity of DNA. Furthermore, with respect to its application to taxonomy, Boivin et al. (1985) have demonstrated the utility of this technique in their taxonomic study of the genus Aquaspirillum.

In electron micrographs (Fig. $4 a, b$ ) whole cells of $C$. helveticus bear a notable resemblance to those of $C$. upsaliensis. The possible occurrence of similar, but unrelated, strains among $C$. upsaliensis was mentioned when that species was first described (Sanstedt \& Ursing, 1991). Studies reporting C. upsaliensis on the basis of only phenotypic identification should therefore probably be re-evaluated for the possible occurrence of $C$. helveticus among strains of $C$. upsaliensis. The salient phenotypic tests for distinguishing $C$. helveticus from $C$. upsaliensis are growth on potato starch medium and reduction of selenite.

Conventional microbiological methods for identifying Campylobacter species have been described by Gebhart et al. (1989) as laborious and subjective. Several groups have therefore employed DNA-DNA hybridization with total genomic DNA probes for the identification of Campylobacter spp. (Fennel et al., 1984; Totten et al., 1985; Burnens \& Nicolet, 1992; Chevrier et al., 1989). Gebhart et al. (1989) reported three cloned speciesspecific probes useful for routine identification and epidemiological studies of $C$. hyointestinalis. We anticipate that the $\mathrm{pCH} 1$ probe will be suitable for identification of $C$. helveticus in bacterial dot-blots (lysis on nylon membranes), for its detection in faecal samples, and for other applications in clinical and epidemiological studies.

At present no information about the distribution of $C$. helveticus, other than in household pets, is available. The species is found in both dogs and cats, but it is noteworthy that almost half the Campylobacter isolates found in cats belong to $C$. helveticus (Burnens et al., 1992). Since knowledge about the occurrence and distribution of $C$. helveticus is limited, no conclusions can yet be drawn about its clinical significance. It is of interest that the new species occurs more frequently in healthy than in diseased household pets, but it should be noted that many Campylobacter spp., such as C. jejuni, 
are found in healthy animals but are pathogenic for man (Newton et al., 1988). Transmission of C. jejuni from diseased cats to humans in the household has been reported (Deming et al., 1987). The possibility of transmission of $C$. helveticus from pets to man would be an important subject of investigation. An analysis of human carriage of $C$. helveticus would also be justified, for instance by comparing occurrence in infectious gastroenteritis patients and healthy controls. Such questions can be addressed through the use of speciesspecific probes such as $\mathrm{pCH} 1$ for further studies of the distribution and mode of transmission of the new species.

\section{Formal description of $C$. heleveticus sp. nov.}

(hel.vetic'us, Latin adjective Swiss; after country of first isolation)

Gram-negative, non-spore-forming rods $1.5-3.0 \mu \mathrm{m}$ in length and $0.2 \mu \mathrm{m}$ in width at $48 \mathrm{~h}$. Cells are regular and slender, with slight spiral curve and rounded ends. Darting motility in hanging-drop preparations of broth cultures. Single amphitrichate polar non-sheathed flagellum. Colonies about $0.5 \mathrm{~mm}$, flat, translucent. Cultures have a spreading, watery appearance on blood agar. Microaerophilic. No growth under anaerobic or aerobic conditions. No growth at $25^{\circ} \mathrm{C}$, but grows at $37^{\circ} \mathrm{C}$ and $42^{\circ} \mathrm{C}$. Oxidase produced. Catalase, alkaline phosphatase, DNAase, and urease not produced. Glucose not fermented. Hydrogen sulphide not produced in triple sugar iron medium. Nitrate reduced. Indoxyl acetate hydrolysed. Selenite not reduced and hippurate not hydrolysed. No growth on potato starch medium. Tolerant to $1 \%$ bile. Resistant to 5 -fluorouracil. Sensitive to nalidixic acid and cephalothin. The $\mathrm{G}+\mathrm{C}$ content of the genomic DNA by the thermal denaturation method is $34 \mathrm{~mol} \%$. Isolated from faeces of diarrhoeic and healthy domestic cats, and more rarely from dogs. Pathogenicity is unknown.

\section{Formal description of the type strain:}

NCTC 12470 is the type strain of $C$. helveticus. This strain conforms to the species description given above.

The $\mathrm{G}+\mathrm{C}$ content of NCTC 12470 DNA is $34 \mathrm{~mol} \%$. The strain was isolated in Switzerland from a domestic cat with diarrhoeal illness. Three additional strains of $C$. helveticus have been deposited in the National Collection of Type Cultures: NCTC 12471, NCTC 12472 and NCTC 12473.

The project was initiated with the support of a British Council grant to J. Stanley for scientific cooperation between the UK and Switzerland. The assistance of M. Egusquiza, B. Lopez, M. Moreno and J. Turnoi is gratefully acknowledged. We thank A. Porter for expert assistance with electron microscopy.

\section{References}

Boivin, M. F., Morris, V. L., Lee-Chan, E. C. M. \& Murray, R. G. E. (1985). Deoxyribonucleic acid relatedness between selected members of the genus Aquaspirillum by slot blot hybridization: Aquaspirillum serpens (Mueller 1786) Hylemon, Wells, Krieg and Jannasch 1973 emended to include Aquaspirillum bengal as a subjective synonym. International Journal of Systematic Bacteriology 35, 512-517.

BuRnens, A. P. \& Nicolet, J. (1992). Detection of Campylobacter upsaliensis in diarrhoeic dogs and cats, using a selective medium with cefoperazone. American Journal of Veterinary Research 53, 48-51.

Burnens, A. P., ANGeloz-wick, B. \& Nicolet, J. (1992). Comparison of Campylobacter carriage rates in diarrhoeic and healthy pet animals. Zentralblatt für Veterinärmedizin 39, 175-180.

Chrvrier, D., Larzul, D., Megraud, F. \& Guesdon, J.-L. (1989). Identification and classification of Campylobacter strains by using nonradioactive DNA probes. Journal of Clinical Microbiology 27, 321-326.

Costas, M. (1992). Classification, identification and typing of bacteria by the analysis of their one-dimensional polyacrylamide gel electrophoresis protein patterns. In Advances in Electrophoresis, vol. 5, pp. 351-408. Edited by A. Chambrach, M. J. Dunn \& B. J. Radola. Weinheim: VCH Verlagsgesellschaft.

Cowan, S. T. (1974). Preparation of culture media. In Cowan and Steel's Manual for the Identification of Medical bacteria, pp. 137-160. Edited by S. T. Cowan. Cambridge: Cambridge University Press.

Deming, M. S., Tauxe, R. V., Blake, P. A., Dixon, S. E., Fowler B. S., Jones, T. S., Lockamy, E. A., Patton, C. M. \& Sikes, R. O. (1987). Campylobacter enteritis at a university: transmission from eating chicken and from cats. American Journal of Epidemiology 126, 526-534.

Dowling, D. N., Samrey, U., Stanley, J. \& Broughton, W. J. (1987). Cloning of Rhizobium leguminosarum genes for competitive nodulation blocking on peas. Journal of Bacteriology 169, 1345-1348.

Fennel, C. L., Totten, P. A., Quinn, T. C., Patton, D. L., Holmes, K. K. \& Stamm, W. E. (1984). Characterization of Campylobacterlike organisms isolated from homosexual men. Journal of Infectious Diseases 149, 58-66.

Franco, D. A. (1988). Campylobacter species: considerations for controlling a food borne pathogen. Journal of Food Protection 51, 145-153.

Gebhart, C. J., Ward, G. E. \& MurTaugh, P. (1989). Species-specific cloned DNA probes for the identification of Campylobacter hyointestinalis. Journal of Clinical Microbiology 27, 2717-2723.

Healing, T. D., Greenwood, M. H. \& Pearson, A. D. (1992). Campylobacters and enteritis. Reviews in Medical Microbiology (in the Press).

LeE, A. S. G. \& MCGeE, J. O'D. (1989). The signal intensity on Southern blots developed by nonisotopic methods is linear with time and quantity of DNA. Nucleic Acids Research 17, 2364.

LIOR, H. \& PATEL, A. (1987). Improved toludine blue-DNA agar for detection of DNA hydrolysis by campylobacters. Journal of Clinical Microbiology 25, 2030-2031.

Newton, C. M., Newell, D. G., Wood, M. \& Baskerville, M. (1988). Campylobacter infection in a closed dog-breeding colony. Veterinary Record 123, 152-154.

ON, S. L. W. \& Holmes, B. (1991a). Effect of inoculum size on the phenotypic characterisation of Campylobacter spp. Journal of Clinical Microbiology 29, 923-926.

ON, S. L. W. \& Holmes, B. (1991b). Reproducibility of tolerance tests that are useful in the identification of campylobacteria. Journal of Clinical Microbiology 29, 1785-1788.

ON, S. L. W. \& Holmes, B. (1992). Assessment of enzyme detection tests useful in identification of campylobacteria. Journal of Clinical Microbiology 30, 746-749. 
OWEN, R. J. (1983). Nucleic acids in the classification of Campylobacters. European Journal of Clinical Microbiology 2, 367-377.

OWEN, R. J. \& PItCheR, D. G. (1985). Chemical methods for estimating DNA base compositions and levels of DNA-DNA hybridization. In Chemical Methods in Bacterial Systematics, pp. 6793. Edited by M. Goodfellow \& D. E. Minnikin. London: Academic Press.

OWEN, R. J. \& BoRman, P. (1987). A rapid biochemical method for purifying high molecular weight bacterial chromosomal DNA for restriction enzyme analysis. Nucleic Acids Research 15, 3631.

OWEN, R. J. \& DAwSON, C. (1986). DNA base compositions and base sequence relatedness of atypical Campylobacter jejuni strains from clinical material. FEMS Microbiology Letters 35, 283-287.

Park, R. W. A., Griffiths, P. L. \& Moreno, G. S. (1991). Sources and survival of Campylobacters: relevance to enteritis and the food industry. Journal of Applied Bacteriology Symposium Supplement 20, 975-1065.

Penner, J. L. (1988). The genus Campylobacter: a decade of progress. Clinical Microbiology Reviews 1, 157-172.

Pitcher, D. G., OWen, R. J., Dyal, P. \& BeCK, A. (1987). Synthesis of a biotinylated DNA probe to detect ribosomal RNA cistrons in Providencia stuartii. FEMS Microbiology Letters 48, 283-287.

Roop, M. R., II, Smibert, R. M., JoHnSON, J. L \& KRIEG, N. R. (1984). Differential characteristics of catalase positive campylobacters correlated with DNA homology groups. Canadian Journal of Microbiology 30, 938-951.

Sambrook, J., Fritsch, E. F. \& Maniatis, T. (1989). Molecular Cloning, a Laboratory Manual. Cold Spring Harbor, NY: Cold Spring Harbor Laboratory.

SANSTEDT, K. \& URSING, J. (1991). Description of Campylobacter upsaliensis sp. nov. previously known as the CNW group. Systematic and Applied Microbiology 14, 39-45.

SkIRrow, M. B. (1990). Campylobacter, Helicobacter and other motile curved gram-negative rods. In Topley \& Wilson's Principles of Bacteriology, Virology and Immunity, 8th edn, vol. 2, pp. 531-549. Edited by M. T. Parker \& B. I. Duerden. London: Edward Arnold.

Tanner, A. C. R., Badger, S., Lal, C.-H., Listgarten, M. A., Visconti, R. A. \& SOCRANSKY, S. S. (1981). Wolinella gen. nov., Wolinella succinogenes (Vibrio succinogenes Wolin et al.) comb. nov., and description of Bacteroides gracilis sp. nov., Wolinella recta $\mathrm{sp}$. nov., Campylobacter concisus sp. nov., and Eikenella corrodens from humans with periodontal disease. International Journal of Systematic Bacteriology 31, 432-445.

TANNer, A. C. R., Listgarten, M. A. \& Ebersole, J. L. (1984). Wolinella curva sp. nov.: "Vibrio succinogenes" of human origin. International Journal of Systematic Bacteriology 34, 275-282.

Totten, P. A., Fennell, C. A., Tenover, F. C., Wezenberg, J. M., Perine, P. L., Stamm, W. E. \& Holmes, K. K. (1985). Campylobacter cinaedi (sp. nov.) and Campylobacter fennelliae (sp. nov.): two new Campylobacter species associated with enteric disease in homosexual men. Journal of Infectious Diseases 151, 131-139.

Vandamme, P. \& DE LeY, J. (1991). Proposal for a new family, Campylobacteriaceae. International Journal of Systematic Bacteriology 41, 451-455.

Vandamme, P., Falsen, E., Rossau, R., Hoste, B., Segers, P., Tytgat, R. \& De LeY, J. (1991). Revision of Campylobacter, Helicobacter and Wolinella taxonomy: emendation of generic descriptions and proposal of Arcobacter gen. nov. International Journal of Systematic Bacteriology 41, 88-103.

WiLson, K. (1987). Preparation of genomic DNA from bacteria. Current Protocols in Molecular Biology, Unit 2.4.1. New York: Wiley.

YANISCH-PERRON, C., VieIRA, J. \& MEssing, J. (1985). Improved M13 phage cloning vectors and host strains: nucleotide sequences of the M13mp18 and pUC19 vectors. Gene 33, 103-119. 